\title{
Human Rights Challenges in Brazil: Children and Vulnerable Persons
}

\section{Guilherme Calmon Nogueira da Gama*}

\begin{abstract}
The vulnerability of children, the elderly and people with disabilities, as minority social groups, attracts special protection not only in Brazilian law, but also in international treaties of human rights. This Article presents an overview of this issue, and identifies the challenges related to the effectiveness of the juridical protection available to these groups.

\section{KEYWORDS}

Constitutional and International Law, Federal Constitution, Minority Groups, Status of Elderly, Children and Persons with Disabilities
\end{abstract}

\section{CONTENTS}

I. Contextualization..................................................................462

II. Human Rights OF CHILDREN......................................................462

III. Human Rights of THE ElderLy.................................................467

IV. Human Rights of Persons with Disabilities ..............................469

V. ConCluding Note...................................................................473

* Permanent Professor of the Stricto Sensu Postgraduate Program in Law at Unesa (Rio de Janeiro, Brazil); Federal Court Judge at the 2nd Region (TRF 2) 


\section{Contextualization}

Seventy years after the promulgation of the 1948 Universal Declaration of Human Rights, the effect of globalization on territorial, physical and informational boundaries is that international law has become increasingly important on the world stage. In the period following the adoption of the Federal Constitution of 1988, Brazilian law started to develop a system aimed at adherence to various international treaties and conventions on human rights, leading to various necessary adjustments to Brazilian domestic law. This Article aims to provide an overview of the extent to which Brazilian law gives effect to the rules of international law in respect of those community groups that are vulnerable by reason of their youth, age or disability. In light of article. $5^{\circ}, \S 2^{\circ}$, of the Brazilian Federal Constitution, the rights of such persons are considered to be fundamental rights not only as expressly provided for by the constitutional text, but also as provided for by international human rights treaties and conventions.

In the course of the twentieth century, there were several movements toward material equality, and the guarantee of equality of all before the law became consistent with the special protection of "unequal" or disadvantaged persons. The gradual protection under the law of consumers, children and adolescents, and various members of minority groups, such as the sick, people with disabilities, transsexuals, homosexuals, among others ${ }^{1}$ resulted from specific equity or nonequity rights situations.

\section{Human Rights OF CHILDREN}

With regard to a couple's family planning, the Brazilian Federal Constitution of 1988 (BR. Const. art. 226, $\S 7^{\circ}$ ) refers to the principle of responsible parenthood. Further examination of this constitutional rule, coupled with other constitutional rules - such as equality between men and women in rights and duties-allows us to conclude that the original constituent power stated less than it wanted, probably because it was misled by the term "parenthood responsibility", ${ }^{2}$ which has another meaning in the context of British law.

So, bearing in mind the caution that needs to be taken when transposing from the British concept to Brazilian law, the originating constituent assembly employed the term "responsible paternity" when, in truth, the sense is that of responsible parenthood. The term is not limited to men, but logically also refers to women and thus its legal effects will give rise to various duties - in the field of relationships-

Id. at 60 .

It is important to note that, in the United Kingdom, parental responsibility was incorporated into the body of the 1989 Children Act as the main concept for the interests and welfare of the child. As Andrew Bainham comments: "The Children Act introduced 'parental responsibility' as the central organizing concept in children law and reasserted the significance of children's welfare as the paramount consideration in disputes concerning their upbringing. It gives to the courts wide-ranging and flexible powers to regulate the exercise of parental responsibility..."; see ANDREW BAINHAM, CHILDREN: THe Modern LaW 28 (2d ed. 1998). 
when exercising reproductive and sexual rights. The notion of responsible parenthood brings with it the inherent idea of the consequences in family law of an individual's exercise of reproductive rights.

Responsible parenthood represents the assumption of parental duties as the result of exercising reproductive rights - either through sexual intercourse or the use of other reproductive techniques, e.g., artificial insemination or in vitro fertilization.

There is individual and social responsibility for both men and women who, in exercising the freedoms inherent in sexuality and procreation, create a new human life whose person - the child - must have their physical and mental well-being prioritized, with all fundamental rights recognized in their favor. Family planning is not only a fundamental right of adults, but at the same time raises responsibilities in the field of parenting. The individual right of a woman to exercise her sexual autonomy to choose maternity must be balanced against the individual and social responsibilities that she takes on in motherhood. In the same way, and specifically in relation to men, the guaranteed individual right to sexuality and choose paternity will have to be balanced against the individual and social responsibilities of fatherhood. In other words, procreation not only brings benefits or advantages to the individual, but imposes the assumption of responsibilities from the conception and birth of the child for the most important aspects of their daily life. This means that parenthood encompasses not only the voluntary aspect of the decision to procreate but a responsibility that continues after the birth of the child and becomes particularly significant during the most important stages of formation and development of the child's personality. Within this meaning, responsible parenthood refers to the notion of care in its ontological dimension - that is, the idea that a person is a conscious and free being who coexists with others, facing the future, needing to be careful to live and survive, but also to care for others, especially those who will represent their continuity into the next generation.

Responsible parenthood stems not only from the individual exercise of choice to become a parent, but may also arise from the consequences of exercising sexual freedom - or even reproductive freedom, in the strictest sense-in the field of parenthood. From this point of view, an important aspect of responsible parenthood is the role of the State and its responsibility to provide the information, resources and family planning techniques, so that people cannot later claim that they did not know the consequences of their individual behavior in the field of sexuality and reproduction.

The principle of a child's best interest represents an important change of axis in the parental-filial relations. The Brazilian Federal Constitution upheld the doctrine of full protection of children and adolescents, which replaced the doctrine previously adopted by the repealed Code of Minors from 1979. Article 227, caput, of the constitutional text expressly establishes that:

[I]t is the duty of the family, society and the State to guarantee the right to life, health, food, education to children, adolescents and young people with absolute priority, leisure, professionalization, culture, dignity, respect, freedom and family and community life, in addition to protecting them from all forms of neglect, discrimination, exploitation, violence, cruelty and oppression. 
This means that the absolute protection of children, adolescents and young people has received constitutional status and falls within the scope of fundamental human rights that have absolute priority over others and are required to be protected by the family, society and the state. ${ }^{3}$

In line with the constitutional text from 1988, the new Statute of the Child and Adolescent (ECA) was promulgated in 1990, and provides insights into the content and effects of the principle of the child's best interests. Article 227 of the Brazilian Federal Constitution, especially when combined with rules of the Statute of the Child and Adolescent, allows us to conclude that the rules protecting the interests and rights of children and adolescents are based on the most upto-date constitutional doctrine. Thus, there was legal recognition that children and adolescents are holders of human and fundamental rights and the subjects of human rights protection. ${ }^{4}$ But such a finding is not enough. The principle of the child's best interests requires that it be fully implemented and observed in the national legal order not only as a general principle, but as a criterion for interpretation and application of the rule of law in matters relating to children and adolescents. $^{5}$

There are specific provisions within the Brazilian ECA that allow us to identify and qualify the principle of the child's best interests not only as a general principle, but in the form of particular requirements in certain aspects involving the child. Thus, for example, in cases of adoption involving adolescents, article $45, \S 2^{\circ}$, of the ECA requires the consent of the adolescent, and not just the consent of the parent or legal representative. In the matter of family planning, naturally, the principle of the child's best interests is highlighted, given the prioritization of their interests and rights over the interests of their parents. In this sense, a couple is not authorized, for example, to choose the gender of the future child (male or female) by using the assisted reproductive techiniques due to the priorization of the child best interests. Additionally, Brazilian ECA also prevents the future child from being economically or physically exploited by parents and that parents use their family planning to give birth of a child with that unlawful intent.

It can be considered that the spectrum of the best interests of the child is not limited to already existing children and adolescents, but also includes fetuses and even to be conceived children as a result of the conscious and responsible exercise of their parents' sexual and reproductive freedoms. In other words, Brazilian Law establishes that, at the moment that a couple is exercising their sexual freedom, they

3 Paulo Luiz Netto Lôbo, Legal Principle of Affectivity in Affiliation, (2000) in The FamiLy ON the Millennium Crossing, 252, 252 (Paulo Luiz Netto Lôbo ed., 2000).

4 Tânia da Silva Pereira and Carolina de Campos Melo define the rights of children and adolescents as fundamental rights doubly guaranteed in the Federal Constitution: "first, expressly, in art. 227, caput, and other related articles, as well as fundamental rights originating from treaties relating to the subject of human rights, see Tânia da Silva Pereira \& Carolina de Campos Melo, Childhood and Youth: Fundamental Rights and Constitutional Principles consolidated in the 1988 Constitution, 3 Q.J. Civ. L., 89 (2000). And thus, the constitutional norms concerning fundamental rights are not susceptible to constitutional amendment.

5 Lia Justiniano dos Santos, Shared Custody: Recommended Model, 8 BraziLian J. Fam. L. 161 (2001). 
have to be conscious about the consequences of the reproductive results of their act, which emcompasses the awareness of a possible to-be-born child's rights ${ }^{6}$.

This is a reformulation of the concept of legal responsibility to cover future generations; and thus, the effectiveness of the principle of a child's best interests in the context of current and parental-filial relationships is fundamental. Such a statement does not apply only to procreation resulting from assisted reproduction techniques, ${ }^{7}$ but also to the product of natural sexual relations between men and women, ${ }^{8}$ even in cases of non-biological reproduction. The principle of the child's best interests should serve as an important protection against the otherwise unrestricted or abusive exercise of reproductive rights, including family planning that encompass the intent to exploit the to-be-conceived child.

In addition to the principle of responsible parenting, article $226, \S 7^{\circ}$ of the Brazilian Federal Constitution provides for the principle of human dignity in the context of family planning Having already referenced this as a valued and fundamental principle in article 1, III, the Brazilian Constitution again refers to the dignity of the human being as a special principle that must be considered in the context of family planning. The dignity of the person, especially when linked to fundamental rights, is usually protected in two distinct ways: (a) the protection of the person in the sense of defending them from any degrading or inhuman act by the State or the community in general; and (b) the promotion of the active participation of the person in the destinies of their own existence and of community life in existential conditions considered fundamental for such coexistence.

How should the dignity of the person be viewed in the context of family planning? It is true that dignity has two dimensions within the scope of most respected legal interests - such as life, physical integrity, honor, intimacy, among others. First, dignity is viewed in the collective dimension - such as the prohibition of arbitrary arrest and deportation - and, second, viewed in the personal dimension, thus representing the need to respect the person considered as such in interpersonal relations - for example, the protection of personality rights, such as the right for life, that means that no one can attempt against the life of another person.

The personal dimension of human dignity imposes a negative general duty to respect individual freedom and the rights arising from the exercise of such freedom, as in the case of reproductive rights. Thus, it is up to the State to protect the dignity of persons who intend to exercise their right of family planning, not only by refraining from any kind of coercive measures by public agencies, but also by preventing the rest of the community from violating those persons' dignity.

6 In that sense, it is important to note that the Brazilian Law only admits abortion in the case of rape or when the pregnancy represents any risk to the mother's life. Except from that, abortion in Brazil is illegal.

7 Heloisa Helena Barbozaalso advocates consideration of the best interests of the child in these matters, especially with regard to surrogate motherhood. See HeLOISA Helena Barboza, Filiation in the Face of Artificial Insemination and In Vitro FERTILizATION 95-96 (1993).

8 In this regard, Luiz Edson Fachin informs about the Canadian experience, in which a plural view of parenthood is observed: "The solutions found to decide, for example, the custody of the child, take into account the interest and the well-being of the child, which authorizes and even recommends, in certain cases, to entrust the child to a third party" see Luiz Edson Fachin, From Paternity 123 (1996). 
The notion of social solidarity is perfectly applicable to the hypothesis, considering that the dignity of the people is not opposed only to the State, but also to society and the people who integrate the collective environment. In Brazil, procreation not only brings benefits or advantages to the individual, but imposes the assumption of responsibilities from the conception and birth of the child for the most important aspects of their daily life, which is important for the society. The dignity of the human being is also appliclable to a future person, that is, the result of the couple's decision to procreate or, as has been stated, the result of accepting the risks of sexual and reproductive freedom. This demonstrates that the dignity of a human being who exercises the right to family planning does not constitute an absolute faculty, finding a limit in the dignity of the child to be conceived and born by virtue of the procreation by that couple. In that sense, when the dignity of the couple that allows itself to make a decision to procreate conflicts with the dignity of the to-be-born child, such conflict, as a rule, must be resolved in favor of the dignity of the child that may still be born.

Thus, considering the principle of a child's best interests, it is clear that the interests to be protected are those of the child and not of the parents, whenever such interests are in conflict. Therefore, the fundamental right to human reproduction has no absolute character, like any other right. In this sense, State action in the fulfillment of the two foreseen functions is vital: (a) to protect the unborn person from degrading and inhuman acts that may be practiced against their dignity; and (b) to promote the minimum conditions necessary for the free and healthy development of their personhood. Such functions, naturally, do not represent the prohibition of having access to assisted human reproduction techniques or contraceptive techniques, but the need to ensure that the interests of those who hold reproductive rights are compatible with the interests of those who may be created as a result of the exercise of such rights.

The administrative-executive branch has the task of providing the information, education and contemporary science resources for the exercise of the right to family planning in a regular and legitimate manner, under the terms of the constitutional provision (art. $226, \S 7^{\circ}$ ). The legislature has the important role of identifying the prevailing community moral, cultural and family values, transforming them into legal values and promoting them in establishing rules regarding family planningas does Law $n^{\circ} 9,263 / 96$, that provides the rules for the couple's exercise of the family planning. And finally, the judiciary system must, in cases of conflicting interests and rights, resolve the specific issues that arise, exercising an important preventive function in some cases-for example, by forbidding access to reproductive techniques when there is no acceptable reason for this (for instance, a woman who does not want to be pregnant because of the changes of her body, and so she chooses to use a surrogate).

This overview of the current situation relating to children in Brazilian law has been instructive, but there is still a lack of effectiveness of human rights and fundamental rights rules in various aspects regarding children. This can be seen, for example, in issues relating to acess to reproductive techniques, adoptions, parental responsabilities, and so on. 


\section{HUMAN RightS OF THE ELDERLY}

In the realm of Brazilian law, due especially to the vulnerability of certain people, certain issues concerning the elderly should also be analyzed in the context of human rights. In current civil law, based on the fundamental principle of human dignity (Federal Constitution, art. 1, item III), the general clause of protection of human beings is based on vulnerability that is inherent in humans and that, in some cases, is exploited - hence the need for separate protection.

Under the terms of art. 230 of the Brazilian Federal Constitution of 1988, "the family, society and the State have the duty to support the elderly, ensuring their participation in the community, defending their dignity and well-being and guaranteeing their right to life." This is an important norm which is absent in Brazilian constitutions predating 1988. The Universal Declaration of Human Rights proclaims the right to security in old age. ${ }^{9}$ The principle of the best interests of the elderly in the Federal Constitution can be identified as a natural consequence of the general clause of protection of human beings, which acts as a source of the full protection that is owed to the elderly. ${ }^{10}$

It is now known that the greatest challenge is not the proclamation of fundamental rights in international normative acts (conventions and treaties on human rights) and domestic acts (Federal Constitution, complementary laws and ordinary laws), in order to recognize the integral and privileged protection of the human being in his existential relations. But rather it is the creation of mechanisms needed to implement them, adapting them to each historical and dynamic moment of a person's life.

Thus, the issue of protection of minorities has gained extreme relevance and timeliness, especially in view of a characteristic common to people in such groups: vulnerability. UNESCO ${ }^{11}$, for example, has already stated that in some cases the majority of the population can be a sociological minority per se, taking into account the distribution of power and to whom the power to make decisions regarding minority rights corresponds. ${ }^{12}$ In UNESCO's view, this difference of distribution of power can make a quantitatively smaller group prevail in decision making process before larger groups. Alessandro Pizzorusso, for example, maintains that the notion of minority must contain two essential elements: (a) those who belong to the minority always form a social group; (b) such group has a position of inferiority within the state community. ${ }^{13}$

Universal Declaration of Human Rights, art. 25, G.A. Res. 217 (III), U.N. Doc. A/80 (1948 ). See also Maria Berenice Dias, Family Rights' Manual 412 (4th ed. 2007).

10 Heloisa Helena Barboza, The Principle of the Best Interest of the Elderly, in CARE AS A Legal Value 57, 57 (Tânia da Silva Pereira \& Guilherme de Oliveira eds., 2008).

11 United Nations Educational, Scientific and Cultural Organization (UNESCO), Documents E/CN.4/Sub.2/SR.647, 648, 673-677, 693-696 and 719-722.

12 Cláudio Marcelo Kiper, Derechos de las Minorías ante la Discriminación 63 (1998).

13 Alessandro Pizzorusso, Le Minoranze nel Diritto Pubblico Interno 182 (1967). 
The term minority should be reserved for social groups that, regardless of their numerical expression, are qualitatively in a situation of inequality, for social, economic or technical reasons, groups subject to the domination of other prevalent groups. ${ }^{14}$

The elderly are considered a vulnerable group, with constitutional recognition in Brazilian law (Federal Constitution, arts. 229 and 230), which has necessitated the issuing of special rules in order to seek effective protection and protection in favor of the elderly segment. Law $n^{\circ}$. 10.741 / 2003 - known as the Statute of the Elderly - was passed to address various aspects related to the legal status of the elderly. Regarding the criteria for elderly status, it opts for age-specifically, the age of $60\left(\operatorname{art.~} 1^{\circ}\right)$. It is recognized that the Statute of the Elderly is a legislative microsystem enabling the prerogatives and rights of older people to be recognized not only in the family, but also in society and by the State.

The Statute of the Elderly provides for cases in which the elderly are at risk. This is the rule contained in art. 43 of the Statute, which provides for the application of measures to protect the elderly when their rights are threatened or violated (a) by action or omission of society or the State; (b) for neglect, omission or abuse by family, healer or caregiver; and (c) by reason of their personal condition. As far as the term 'elderly' is concerned, there is no statutory or constitutional definition. According to the World Health Organization (WHO) "most developed world countries have accepted the chronological age of 65 years as a definition of "elderly' or older person", ${ }^{15}$ but the terms "aging" and "age" are not synonymous and there is no necessary correlationbetween age and cognitive deficiency. Under Art. $2^{\circ}$, of the Statute of the Elderly, the elderly are accorded possession and enjoyment of all human and fundamental rights, ensuring all opportunities and facilities for the preservation of their physical and mental health, their moral, intellectual, spiritual and social improvement, under conditions of freedom and equality. These rights are based on the supreme principle of the dignity of human beings under Brazilian law, which seeks to ensure concretely the autonomy of the elderly and their effective participation in life in society. It is, therefore, another instance of special protection, based on the notion of integral protection of the elderly and the principle of material equality in order to provide separate protection to those who are in a particularly vulnerable situation. ${ }^{16}$

Art. $8^{\circ}$ of the Statute of the Elderly, provides for aging as a very personal right, and its protection is considered a social right. The vulnerable status of the elderly is justified by some factors related to advanced age, such as loneliness, physical and mental fragility, interruption of productive activity. This generates a sociocultural tendency toward the marginalization or infantilization of the elderly, making them "invisible" or nonautonomous. The notion of "active aging" - that is, the process of optimizing health, participation and safety opportunities for the elderly with the aim of improving their quality of life as they age - should be pursued by society in light of the principles stated in the Statute of the Elderly. ${ }^{17}$

\footnotetext{
Barboza, supra note 13, at 60 .

https://www.who.int/healthinfo/survey/ageingdefnolder/en/.

Barboza, supra note 13, at 65.

Guilherme Calmon Nogueira da Gama \& Marina Lacerda Nunes, Elderly People with Alzheimer's: Dialogues between the Federal Constitution, the Elderly Statute and the
} 
The specific evidence of the elderly's vulnerability deserves to be highlighted when compared to the legal condition of children and adolescents. While a child is in the process of physical, mental and intellectual development, becoming recognized as completely autonomous, the elderly require a separate type of protection to maintain their autonomy. In other words, while the child and the adolescent, also considered incapable, are protected in such a way as to enable their development as empowered by their autonomy, especially in the non-patrimonial-but also in the patrimonial-sense, the elderly face threats to their autonomy due to the natural consequences of old age, which would imply a change of their legal status from a competent to incompetent person.

Law $n^{\circ} 10.741 / 2003$ presents a list of rights and guarantees that provide effective compliance with the principle of material equality related to the elderly in order to enforce the general clause of protection of human beings. Such rights and guarantees include: rights to live, to be healthy, to have acess to education, to culture, to sports, to enteirtanment, to the work, to freedom, to dignity, to respect and to live together with theis families and communities (art. 3 of the Statute of Elderly).

Thus, it is observed that there are important advances in themes related to the protection of the elderly, but it is essential to raise awareness of the rights and prerogatives conferred on the elderly, which demand the attention of the government, especially regarding the development and implementation of policies, as well as the awareness and enforcement of rights ensured by the Statute of the Elderly and the Civil Code.

\section{Human Rights of Persons with Disabilities}

The Statute of Persons with Disabilities (SPD - Law n ${ }^{\circ}$. 13.146/15) has emerged as a consequence in recent decades of a global movement for the recognition of the rights of persons with disabilities, culminating in the promulgation of the UN International Convention on the Rights of Persons with Disabilities (CRPD), to which Brazil is a signatory. The CRPD was incorporated into Brazilian law via Decree $n^{\circ} .6,949 / 2009$, through the process of article $5^{\circ}, \S 3^{\circ}$, of the Federal Constitution, providing constitutional status for its rules ${ }^{18}$. However, only with the establishment of the SPD did the guidelines of that convention come to fruition in the ordinary part of Brazilian Law, that is the changes about inclusion of people with the disabilities in society, with the recognition of their dignity, autonomy, among others rights. ${ }^{19}$ The CRDP inserted the principles of autonomy and capacity

Disabled Persons Statute, in The Legal GuARDianship of THe ElderLy 93, 93 (Fabiana Rodrigues Barletta \&Vitor Almeida eds., 2020).

18 In Brazil, the legislative process provides that international human rights treaties and conventions, when internalized according to qualified legislative quorum, will have the status of constitutional norm, that is, hierarchically superior to other ordinary laws.

19 The main contribution of the SPD is to regulate in the infra-constitutional plan the norms of the Convention on the Rights of Persons with Disabilities, presenting its own contours of application of some conventional norms to the reality of the Brazilian legal order see Flávia Piva Almeida Leite\& Lauro Luiz Gomes Ribeiro \&Waldir Macieira Costa Filho, Comments on the Statute of Persons with Disabilities 42 (2016). 
of persons with disabilities, making the placement of the person in curatela regime an extraordinary instrument and restricted in scope to acts of patrimonial and business nature. ${ }^{20}$

The Convention on the Rights of Persons with Disabilities was approved by Legislative Decree $n^{\circ}$. 186, of July 9, 2008, and promulgated by Decree $n^{\circ}$. 6,949 , of August 25, 2009, being incorporated into the Brazilian legal system by the process of article $5^{\circ}, \S 3^{\circ}$ of the Brazilian Federal Constitution (approval in each House of the National Congress, in two rounds, by the quorum of three-fifths of the vote by their respective members). This is the first treaty of the twenty-first-century universal human rights system incorporated into Brazilian law, which is based on the principles of in dubio pro capacitas and "minimal intervention." In this sense, it promotes a transformation in the way in which the law regards persons with disabilities and the protective law model based on guardianship (curatela), turning to a model that recognizes the autonomy and capacity of all people, even the person with disability. ${ }^{21}$

This International Convention introduces a new, open and social conception of persons with disabilities in its art. $1^{\circ}$ as "those who have long-term impediments of a physical, mental, intellectual or sensory nature, which, in interaction with various barriers, may obstruct their full and effective participation in society on equal terms with others." It is inferred, therefore, that disability is not defined as the absence of a limb, nor the impairment of hearing or the presence of a mental illness-i.e., disability is not defined by the physical ailment itself, but in the obstacles those with disabilities face to effectively integrate themselves in society. Hence, the CRDP applied the social model, as opposed to the medical model, which is marked by its categorization of people by the nature of their disability according to the appropriate scientific classification: mental, intellectual, physical or sensory (e.g., hearing and visual) impairment.

The purpose of the Convention, stated in its art. $1^{\circ}$, is to "promote, protect and ensure the full and equitable exercise of all human rights and fundamental freedoms by all persons with disabilities and promote respect for their inherent dignity." The international legislation has been more concerned with ensuring that people with disabilities can enjoy human rights and their fundamental freedoms rather than creating new rights. To achieve this, the legislature adopted a set of equality conditions, including the wording of the second part of art. 1, which includes a definition of "people with disabilities," confirming the idea that social barriers can disrupt this group's ability to participate in society on an equal basis with other people. $^{22}$

$20 \quad$ Waldir Macieira da Costa Filho, Reflections on Law no. 13.146, the Design of Disability and Legal Capacity and Supported Decision Making, 9 J. OF THE PuB. Prosecution Serv. Of the St. of PARÁ 254 (2016).

21 Joyceane Bezerra de Menezes, Protective Law in Brazil after the Convention on the Protection of Persons with Disabilities: Impacts of the New CPC and the Statute of Persons with Disabilities, Civilistica.com (2015), http://civilistica.com/wp-content/ uploads/2016/01/Menezes-civilistica.com-a.4.n.1.2015.pdf(last accessed May 1, 2020).

22 Ana Paula Crosara Resende \& Flávia Maria de Paula, A Convenção Sobre os Direitos das Pessoas com Deficiência Comentada,(2008) Available at: http://www.stf.jus.br/repositorio/ $\mathrm{cms} /$ portalTvJustica/portalTvJusticaNoticia/anexo/Convencao_Comentada.pdf. 
For the international legislature, the more that equal conditions between persons with disabilities and those without disabilities are ensured, the greater the realization of the dignity of the former and, consequently, the free exercise of their fundamental freedoms will be. Equality presupposes respect for personal differences. Rather than leveling individual personalities, effective and substantial equality manifests itself precisely by taking into account the distinct peculiarities of each person.

In short, the Convention on the Rights of Persons with Disabilities seeks to overcome external barriers in order to prepare society for the integration of persons with disabilities by managing their differences and supporting the ability to live with diversity without feeling threatened by it. Article 12 of the Convention on the Rights of Persons with Disabilities, by insisting on the right to equality before the law, reinforces the legal capacity of these people for all life issues on equal terms with others, intending to endow them with "the possibility of conducting their own interests in the exercise of their creative capacity and their volitional expression, fruit of the autonomy that qualifies them in their humanity." 23

In this regard, the Convention on the Rights of Persons with Disabilities has stipulated that the signatory states shall provide support and safeguard mechanisms, where necessary, for persons with disabilities to exercise thei bv $r$ rights to their utmost capacity ${ }^{24}$. While not strictly determining what the support instruments should be, it defines safeguards as precautions or measures designed to prevent abuse, excesses or illegalities that may be caused by improper use of support mechanisms in accordance with international human rights law.

Each state is sovereign in determining the methods of support that it deems appropriate and useful for the exercise of rights by persons with disabilities, always taking into consideration their wishes and preferences. Such support should be appropriate to the circumstances in which the person finds himself/herself, applied for the shortest possible period and subject to regular review by a competent, independent and impartial judicial authority or body. Thus, safeguards should be commensurate with the extent to which such support mechanisms affect a person's rights and interests.

In Brazil, until January 2016, the appointment of a curatela or guardian was the main method of support; ${ }^{25}$ however, with the creation of the Disability Statute, Supported Decision Making was established, significantly modifying the 2002 Civil Code. In addition to civil capacity, the CRPD highlighted other issues directly associated with civil law: the right of persons with disabilities to psychophysical integrity (art. 17); freedom of movement and nationality (art. 18); independent living and inclusion in the community, allowing them to choose their place of residence and with whom they wish to live so that they are not compelled to live in a particular type of dwelling (art. 19); substantial mobility (art. 20); freedom of expression and opinion (art. 21); right to privacy (art. 22); the right to the constitution and protection of the family (art. 23), imposing on the states the obligation to ensure that the person with disabilities has the capacity and possibility to exercise family

\footnotetext{
Bezerra de Menezes, supra note 23, at 8.

24 UN International Convention on the Rights of Persons with Disabilities (CRPD)United Nations, Art. 12. 2. e 3.

25 A 'curatela' or curator is a judicially appointed trustee charged with taking care of the affairs of a person incapable of managing their property and affairs. The extent of the curatela's duties is defined by the judge.
} 
power ${ }^{26}$ and leadership, custody, the guardianship (curatela) and the power to adopt children, always with the child's best interests in mind.

The most important contribution of the U.N. Convention is in recognizing the autonomy and capacity of persons with disabilities, on an equal basis with others, thus preserving their dignity and participation in social, family and political life. Autonomy or the capacity for self-determination, the material foundation of one's ability to act, translates into a human necessity from which various rights are derived. Everyone has, to a lesser or greater extent, the capacity to plan and decide for themselves. Cognitive capacity is considered to be the criterion guiding the exercise of this ability, especially when the choices have legal impact on the person or others. The focus, however, is not on the medical diagnosis of a psychological or intellectual disability per se, but on the necessity for self-determination.

From a legal perspective the challenge is to determine whether the person with disabilities has the capacity to perform acts that have legal consequences for agents or third parties, receiving its own recognition of "legal capacity." Such recognition has impact in several practical events. Civil law, for example, requires that the parties have the legal capacity to enter into binding agreements, especially those of a business and equity/economic nature. Therefore, regarding legal facts or relevant actions, there would be no need to discuss disability because, in this context, there is no requirement of purpose or understanding, meaning, as a rule, that people with disabilities are able, unless put into guardianship regime (curatela), to exercise its legal capacity to perform civil rights and acts.

The aim of the Convention on the Rights of Persons with Disabilities is to rely on the autonomy of people with disabilities on equal terms with individuals who do not have disabilities, thereby affirming their condition and ability to decide matters important to their lives without interference, a priori, by third parties. If, despite any lasting physical, mental or intellectual limitations, a person has preserved the judgment necessary to perform a specific civil act and is able to express his intention, there is no need for representation or assistance by a third party to exercise his rights and perform duties.

In Brazil, civil law differentiates acts of an equity, non-equity and mixed (both non-equity and equity) nature. By way of example, legal relationships that create obligations, sometimes translated into contracts or those involving real estate, such as property, usufruct or easements, are equity in nature, whereas marriage, the disposition of one's own body, elective medical treatment, recognition of a child, religious and professional freedom, living wills, appointment of a guardian or curator are acts concerning the whole human condition. The will (last testament), as well as antenuptial covenants, the administration of children's property and food, encompass equity and informal interests in people's lives, as they are associated with intra-familial relationships.

Depending on the type of civil act, a certain level of understanding is required. It is evident that the discernment required for the performance of civil acts of a equity nature is not the same as that required for non-equity acts, since they are situated in different spheres. The former encompasses more technical and legal

26 According to Brazilian Law, the family power encompasses the power/duty that parents have over their children. In the present case, the Law reconizes that even a person with a mental disability has family power over their children, bearing custody over the children, exercising the property rights of the children and so on. 
information that is less subjective, while the latter is more closely linked to one's personal ties, preferences and circumstances, i.e., one's unique way of being. ${ }^{27}$

A person with a mental or intellectual deficiency may have a harder time understanding the consequences of a buy-and-sell agreement or the dynamics of corporate governance, requiring the action of a curator or the support of a third party. On the other hand, this same person can add conditions for understanding and deciding on issues related to their personal and affective life, such as where they want to live, who they want to live with, who they want to relate to, or who appeals to them as their supporter/healer.

While equity legal affairs are reflected in the available sphere of the individual, non-equity civil acts reach unavailable, non-transferable and generally irrevocable interests, not being able to be represented (e.g., via living will) most of the time, because the person who has the right must personally practice the act. Due to the contiguity between non-equity interests and the principles of human dignity, psychophysical integrity, equality and the free development of personality, constitutional protection toward the decision-making autonomy of the subject in this field is intensified.

It is encouraged that the person, even if using mechanisms of support or additional care by third parties or the public power due to a psychological or intellectual diability, should manage their daily affairs, as this contributes to the quality of their life and personal identity.

\section{Concluding Note}

Brazilian law is at the forefront in comparison with other national legislations in ascpects related to incorporating important international treaties and conventions concerning the human rights of the most vulnerable, such as children, the elderly and people with disabilities. The main challenge nowadays is to implement the rights provided for by Brazilian law, with the emphasis on those treaties that have the status of constitutional norms and are therefore hierarchically superior to the ordinary rules, meaning that such ordinary rules shall be always interpreted according to the constitutional provisions or disregarded in case of material conflicts with constitutional provisions.

Admittedly, the law alone does not perform the function of modifying the cultural reality that exists in a given legal system and country and, therefore, the current challenge faced in legal issues regarding the rights of children, the elderly and people with disabilities is to give practical effect to the international, constitutional and domestic laws that protect the interests of the most vulnerable in civil society. To this end, it is essential that organized civil movements (e.g. elderly, children and people with disabilities's defense organizations and other protective foundations) act to protect the interests of the most vulnerable people and that public policies aimed at informing and realizing the fundamental and human rights of children, the elderly and people with disabilities are developed.

27 Bezerra de Menezes, supra note 23, at n.8. 